\title{
Impacto do Computador nos Princípios de Administração
}

\author{
ROBERT B. PARSONS \\ Vice-Presidente das Ciências da \\ Computação da Eastern Airlines \\ "Advanced Management Journal" \\ New York, 33(4): 51-33, oct, 1968
}

Tradução de Maria José da Luz V. M. de Oliveira (Bibliotecária, UnB)

A aura romântica que envolveu os computadores aguçou sutilmente a vigilância dos gerentes quanto à necessidade de mudança, e a aura romântica enfatizou também a desejabilidade da mudança.

0 pessoal que vive no mundo dos computadores, como eu, está sendo obrigado a adotar um corpo de princípios de administração. Tentamos evitá-lo; mas apesar das misteriosas Palavras que usamos para sugerir a nossos patröes que nós deveriamos ser mais bem pagos, sabemos que os computadores são instrumentos e nada mais.

Embora não fôsse o caso, fiquei nada menos que vagamente surprêso ao descobrir que o breve corpo de Princípios enunciado por um meu antigo patrão aplica-se ao mundo em que agora vivo. Êle resumia tôda sua filoSofia administrativa dizendo: "Quero que todo mundo aqui em volta seja feliz, mas nós não vamos bancar os Íliotas por causa disso".
Neste curto artigo, tentarei explicar por que acredito que esta declaração de princípios muito sadia ainda se aplica, apesar do crescente impacto dos computadores sôbre a administração. Para começar, do momento em que uma pessoa aceita $\circ$ fato de que 0 computador não é mais que um instrumento - um poderoso instrumento,

Robert B. Parsons foi recentemente nomeado Vice-Presidente das Ciências da Computação da Eastern Airlines, depois de haver servido como Vice-Presidente do Conselho do Serviço de Dados. Antes de ligar-se à Eastern, foi Diretor da Delta Air Line's Electronic Reservation System. Começou sua carreira de aviador em 1946 como encarregado dos transportes de mercadorias e, quando a Delta C\&S se desfêz, foi nomeado Encarregado-Geral. Normalmente êle funciona como Vice-Presidente da Subcomissão da IATA Data Processing, bem como Vice-Presidente da Comissão Consultiva para Administradores na Florida Atlantic University. 
certamente - então pode aceitar o fato de que os dogmas básicos da adminlstração saudável na realidade não foram afetados. Tudo que o computador pode fazer é dar à gerência a possibilidade de colocar aquêles princípios básicos em uso mais eficaz. Não aceito a proposição de que os computadores estão mudando os princípios de administração.

Por exemplo, quando os computadores entraram pela primeira vez em uso generalizado, as mais populares aplicaçöes foram as que eram ou soluçőes únicas para problemas complexos, ou aplicações à substituição de pessoal, limitadas a organizações individuais.

Hoje, entretanto, entendemos que os maiores lucros estão naquelas áreas que afetam as atividades de diversos departamentos. Como resultado, os interrelacionamentos departamentais passaram a merecer cuidadosa atenção e as vantagens da abordagem em equipe lavadas a grau nunca antes possivel.

Os computadores igualmente nos fizeram perceber que tem havido uma insidiosa tendência por parte de todo mundo para desperdiçar seu mais precioso recurso: sêres humanos. Os gerentes notaram há séculos que o rendimento de suas emprêsas é função da extensão em que êles podem dar ao seu pessoal instrumentos mais poderosos para serem usados no processo de produção.

\section{A INUNDAÇĀO DE PAPEL}

Mas apesar dos progressos em ferramentas para uso no manejo do trabalho burocrático e na comunicação entre pessoas, a verdade é que ainda as montanhas de papel continuam amarrando mais e mais pessoas no desempenho de tarefas que, em última análise, não criam verdadeira riqueza. De fato, na extensão em que as pessoas têm de desempenhar tarefas repetitivas, mais e mais erros são cometidos.

Eu chamaria isto de a maior vantagem dos computadores. Pela primeira vez, a direção está em posição de libertar-se para pensar ao invés de desempenhar funções repetitivas sujeitas a erros. Os computadores diminuem a necessidade de sêres humanos manejarem pormenores servis, e o tempo recentemente disponivel pode ser aplicado excepcionalmente; isto é, para lidar com problemas ao invés de pormenores e exercer julgamentos como apenas sêres humanos podem fazer.

Os computadores fazem outras coisas bem, e cada uma delas reforçam a proposição de que os princípios de administração podem tornar-se um modo de vida e não apenas metas parcialmente atingíveis. Deixe-me citar apenas algumas das áreas onde os computadores têm produzido êstes efeitos altamente benéficos:

Aquêles gerentes que participaram do desenvolvimento da mais simples abordagem computadorizada de um problema sabem que - projeto obriga as pessoas a formular um plano; a organizar para atacar o problema; e coordenar as atividades daqueles que trabalham no projeto. Para declarar o óbvio, êstes são os três primeiros princípios de qualquer filosofia da administração.

- Como aquêles gerentes que eståo familiarizados com a computaçăo 
em tempo real sabem, os computadores tendem a destacar os erros. Muito freqüentemente, os gerentes são tentados a crer que a própria aplicação do computador é que trouxe os erros no sistema antes dirigido por sêres humanos. Mas mais freqüentemente, os erros que os computadores magnificam são, na verdade, erros que as pessoas podem esconder ou ignorar. Para tornar a declarar o óbvio, o computador põe o gerente em posição de resolver problemas, corrigir erros, e melhorar seu produto de uma forma que era impossivel com o processo baseado inteiramente em sêres humanos.

- $E$, como aquêles gerentes que se queixaram tão a $\mathrm{m}$ a rg a m en te quando o curso do processamento de dados estava atrasado sabem, as aplicações do computador tendem a forçar os sêres humanos envolvidos naquelas aplicações a executar suas responsabilidades a tempo e a hora. Os gerentes sabem instintivamente que pessoal bem treinado é essencial para o êxito. E no entanto, tendemos a colocar o treinamento no final de nossas prioridades. Mas como a instrução aumentada pelo computador se torna cada vez mais largamente usada - e uma explosão está a ponto de acontecer na indústria das linhas aéreas nesse terreno - então nós, como gerentes, seremos obrigados a nos apresentarmos cada vez melhor, quase à revelia.
Quando nos transferimos do processamento batch para o tempo real, descobriremos que os computadores têm outro papel na prevenção de erros. Imissões para um sistema de tempo real podem ser corrigidas dos erros óbvios antes de serem aceitos. Mais que isso, o tempo real elimina largamente a possibilidade de desentendimentos entre sêres humanos e permite a cada qual trabalhar baseado na mesma fôIha de papel.

O fato de os computadores poderem desempenhar tantos trabalhos servis que os humanos tiveram de executar até recentes anos, significa que êle melhora imensamente nossa habilidade de reduzir custos unitários. Isto põe dinheiro no bôlso de todo mundo.

- Similarmente, os computadores elevam os empregos e tornam os seres humanos muito mais produtivos. Penso que é incontestável que os computadores têm, no final das contas, tido um impacto enorme nos ganhos médios. Isto se aplica a todo mundo e não apenas ao pessoal que é mais bem pago por serem agora operadores, programadores ou criadores de novos sistemas.

- Gostaria também de mencionar o fato de que os computadores tornam possivel provar se as pessoas estão trabalhando tanto como alegam.

Óbviamente, há muitos outros impactos. Deixe-me apenas mencionar mais dois para terminar. Primeiro, a aura romântica que envolveu os computadores aguçou sutilmente a vi- 
gilância dos gerentes quanto à necessidade de mudança, e a aura romântica enfatizou também a desejabilidade da mudança. Mas do que tudo, sugeriu que a mudança é possível - que não temos de nos contentar com o status quo e nos tornarmos progressivamente imersos num mar incontrolável de papel.

Segundo, a informação administrativa que pode jorrar de sistemas de contrôles operacionais computadorizados pode tornar a administração mais alerta quanto às mudanças num am- biente que opera dinâmicamente. Pode ser dito, de fato, que o êxito futuro será determinado em grande parte pela extensão em que a administração usar computadores para ajustar suas emprêsas às mudanças na sua posição de concorrência.

Resumindo, os computadores trouxeram um instrumento imensamente poderoso para os gerentes. Mas apenas fortaleceram os princípios de administração que já conhecemos. Năo os mudaram. 